\title{
A new Puercan (early Paleocene) hyopsodontid "condylarth" from New Mexico
}

Thomas E. Williamson and Anne Weil

Acta Palaeontologica Polonica 56 (2), 2011: 247-255 doi: http://dx.doi.org/10.4202/app.2009.0147

Isolated cheek teeth from the late Puercan (early Paleocene) Split Lip Flats local fauna, from the head of Willow Wash, Nacimiento Formation, San Juan Basin, represent a new genus and species of hyopsodontid "condylarth", Chacomylus sladei. The teeth are small, bunodont, and are remarkable for the enlargement of the protocone, pronounced exodaenodonty, and high degree of attritional wear caused by transverse shearing or grinding. Although $C$. sladei bears a superficial resemblance to the apheliscine apheliscid Gingerichia, a preliminary phylogenetic analysis confirms that it is a hyopsodontid, closely related to the Puercan hyopsodontids Valenia wilsoni and Litomylus orthronepius.

Key words: Mammalia, Condylartha, Hyopsodontidae, Puercan, Paleocene, Nacimiento Formation, New Mexico.

Thomas E. Williamson [thomas.williamson@state.nm.us], New Mexico Museum of Natural History and Science, 1801 Mountain Rd, NW, Albuquerque, NM 87104; Anne Weil [anne.weil@okstate.edu], Oklahoma State University Center for Health Sciences Department of Anatomy and Cell Biology, 1111 West 17th St., Tulsa, OK 74107-1898.

This is an open-access article distributed under the terms of the Creative Commons Attribution License (for details please see creativecommons.org), which permits unrestricted use, distribution, and reproduction in any medium, provided the original author and source are credited. 
